\title{
PENGARUH KUALITAS PRODUK TERHADAP KEPUTUSAN PEMBELIAN MOBIL TOYOTA YARIS DI WIJAYA TOYOTA DAGO BANDUNG
}

\author{
Yeni Andriyani \\ Wandy Zulkarnaen \\ STIE Muhammadiyah Bandung \\ Jl. Karapitan No.143 Bandung
}

\begin{abstract}
Abstrak
Dalam perkembangan konsep pemasaran mutakhir, konsumen ditempatkan sebagai pusat perhatian. Dalam proses keputusan pembelian memerlukan suatu upaya dari perusahaan agar produknya dapat sampai ke tangan konsumen, paling tidak perusahaan tersebut berusaha untuk mengubah perilaku konsumen dari rasa ingin tahu mengenai produk yang ditawarkan perusahaan menjadi rasa tertarik, bahkan dari rasa tertarik tersebut meningkat sampai pada adanya keinginan untuk memiliki produk sehingga konsumen tersebut akan mengambil keputusan pembelian terhadap produk yang ditawarkan oleh perusahaan.

Metode penelitian yang digunakan adalah metode deskriptif dengan membuat deskripsi, gambaran atau lukisan secara sistematis, faktual dan akurat megenai faktafakta, sifat-sifat serta hubungan antar fenomena yang diselidiki. Dimana hubungan yang diteliti antara kualitas produk sebagai sebagai vaiabel $\mathrm{X}$ dan proses keputusan pembelian sebagai variabel Y.

Hasil penelitian menunjukkan persamaan regresi dengan persamaan regresi sebagai berikut : $\mathrm{Y}=9,365+0,917 \mathrm{X}$, Dari persamaan regresi tersebut dapat dilihat bahwa koefisien regresi $\left(\beta_{\mathrm{i}}\right)$ untuk variabel Kualitas Produk $(\mathrm{X})$ bertanda positif, artinya variabel tersebut berpengaruh positif terhadap Keputusan Pembelian (Y). Variabel Kualitas Produk (X) memiliki nilai koefisien regresi $\left(b_{i}\right)$ sebesar 0,917. Hal ini menunjukkan bahwa setiap peningkatan variabel Kualitas Produk (X) satu satuan nilai akan meningkatkan Keputusan Pembelian (Y) 0,917 satuan nilai, dengan asumsi variabel lainnya nol.
\end{abstract}

Kata kunci : Kualitas Produk dan Keputusan Pembelian

PENDAHULUAN

UU Perlindungan Konsumen

Nomor 8 Tahun 1999 Tentang

Perlindungan Konsumen Republik

Indonesia menjelaskan bahwa hak

konsumen diantaranya adalah hak atas kenyamanan, keamanan, dan keselamatan dalam mengonsumsi barang dan atau jasa; hak untuk memilih barang dan atau jasa serta mendapatkan barang dan atau jasa tersebut sesuai dengan nilai tukar dan kondisi serta jaminan yang 
dijanjikan; hak untuk diperlakukan atau dilayani secara benar dan jujur serta tidak diskriminatif;hak untuk mendapatkan kompensasi,ganti rugi dan atau penggantian, apabila barang dan atau jasa yang diterima tidak sesuai dengan perjanjian atau tidak sebagaimana mestinya; dan sebagainya.

Perkembangan usaha dewasa ini telah diwarnai dengan berbagai macam persaingan di segala bidang. Melihat kondisi tersebut menyebabkan pebisnis semakin dituntut untuk mempunyai strategi yang tepat dalam memenuhi target volume penjualan. Mengingat perkembangan teknologi yang makin dinamis, manusia dituntut dengan cepat dan tepat untuk bertindak agar tidak kalah bersaing.

Untuk meningkatkan persaingan masing-masing perusahaan harus dapat memenangkan persaingan tersebut dengan menampilkan produk yang terbaik dan dapat memenuhi selera konsumen yang selalu berkembang dan berubah-ubah. Seiring dengan perkembangan jaman dan semakin meningkatnya kebutuhan alat transpotasi membawa angin segar bagi perusahaan otomotif terutama di bidang sepeda motor, yang mana sangat dibutuhkan oleh banyak orang selain harganya terjangkau dan mudah perawatannya juga teknologinya yang inovatif dan nyaman digunakan (Kotler, 2010:34).

Kondisi dari industri kendaraan bermotor di Indonesia sendiri, dewasa ini makin semarak dengan banyaknya pemain baru yang terlihat dalam industri ini, sehingga memaksa para produsen kendaraan bermotor menghadapi persaingan yang lebih ketat, terutama dengan masuknya produk- produk otomotif dari Korea Selatan yang mulai masuk ke pasar Indonesia sekitar tahun 2010-2013 dengan menjual mobil yang sekelas dengan mobil-mobil produk Jepang dan Eropa.

Bulan Februari tahun 2006, merek unggulan seperti Toyota meluncurkan kendaraan dengan variabel baru yaitu YARIS yaitu kendaraan hatchback pertamanya yang hadir di kelas 4x2 medium mini. Dikelas ini Toyota Yaris bersaing dengan merek-merek seperti Suzuki merilis Swift, Honda merilis Jazz, Mazda merilis Mazda 2, KIA dengan Picanto.

Berikut daftar mobil terlaris 2016 :

\section{Tabel 1. Data Penjualan Mobil}

Terlaris 2016 Nasional

\begin{tabular}{|c|c|c|c|}
\hline $\mathrm{NO}$ & MODEL & PENJUALAN & Persentase \\
\hline 1 & $\begin{array}{l}\text { Toyota } \\
\text { Avanza }\end{array}$ & 122.654 unit & $24 \%$ \\
\hline 2 & $\begin{array}{l}\text { Toyota } \\
\text { Kijang } \\
\text { Innova }\end{array}$ & 57.483 unit & $12 \%$ \\
\hline 3 & $\begin{array}{l}\text { Toyota } \\
\text { Calya }\end{array}$ & 47.287 unit & $11 \%$ \\
\hline 4 & $\begin{array}{l}\text { Toyoya } \\
\text { Agya }\end{array}$ & 45.008 unit & $10 \%$ \\
\hline 5 & $\begin{array}{l}\text { Daihatsu } \\
\text { Xenia }\end{array}$ & 44.720 unit & $8 \%$ \\
\hline 6 & $\begin{array}{l}\text { Honda } \\
\text { HR-V }\end{array}$ & 44.331 unit & $8 \%$ \\
\hline 7 & $\begin{array}{l}\text { Toyota } \\
\text { Yaris }\end{array}$ & 38.482 unit & $7 \%$ \\
\hline 8 & $\begin{array}{l}\text { Honda } \\
\text { Jazz }\end{array}$ & 38.087 unit & $7 \%$ \\
\hline 9 & $\begin{array}{l}\text { Daihatsu } \\
\text { Ayla }\end{array}$ & 38.666 unit & $7 \%$ \\
\hline \multirow[t]{2}{*}{10} & $\begin{array}{l}\text { Honda } \\
\text { Brio Satya }\end{array}$ & 36.470 unit & $6 \%$ \\
\hline & Jumlah & 513.188 unit & $100 \%$ \\
\hline
\end{tabular}

\section{Sumber Data: Gaikindo}


Berdasarkan tabel diatas data penjualan mobil terlaris 2016, untuk mobil Hatchback mini masih dipimpin oleh Toyota Yaris dengan penjualan yang mencapai 38.482 unit bila dibandingkan dengan merk lainnya pada tahun 2016 total penjualan produk Toyota Yaris diatas merek mobil Honda Jazz yang merupakan pesaing terberat Toyota Yaris. tetapi untuk periode Tahun 2016, Sebernarnya target Toyota untuk pengguna yaris lebih kepada anak muda yang gaul dan responsif dalam menjelajahi jalan dalam maupun luar kota. Selain itu juga Toyota Yaris juga sering digunakan untuk ajang slalom atau drift yang disukai kalangan anak muda yang trendi.

Meskipun begitu data penjualan yaris masih kalah bila dibandingkan produk toyota lain, untuk segmen MPV masih dikuasai oleh mobil sejuta umat yaitu Toyota Avanza dengan penjualan yang mencapai 122.654 unit. Bila di segmentasikan produk Toyota memiliki target nya masing-masing, misalnya untuk mobil Toyota Avanza memiliki segmen MPV atau mobil keluarga yang dimana targetnya yaitu keluarga yang bisa untuk dipakai dalam atau luar kota bahkan dapat digunakan untuk liburan bersama keluarga. Sedangkan target Toyota untuk pengguna yaris lebih kepada anak muda yang gaul dan responsif dalam menjelajahi jalan dalam maupun luar kota. Selain itu juga Toyota Yaris juga sering digunakan untuk ajang slalom atau drift yang disukai kalangan anak muda yang trendi. Namun untuk mobil sedan Toyota memiliki Camry yang termasuk golongan Medium Class Sedan dimana targetnya para pemimpin perusahaan yang memiliki kelas yang tinggi. Dengan penjualan sebesar 1.193 unit.

berbagai

Berikut daftar mobil toyota di segmen:

Tabel 2. Data Penjualan Mobil Berbagai Segmen Tahun 2016

\begin{tabular}{|l|l|l|r|r|}
\hline NO & \multicolumn{1}{|c|}{ TYPE } & \multicolumn{1}{c|}{ MODEL } & PENJUALAN & PERSENTASE \\
\hline 1 & MPV/ Keluarga & Avanza & 122.654 unit & $70 \%$ \\
\hline 2 & Hatchback & Yaris & 38.482 unit & $24 \%$ \\
\hline 3 & Medium Class Sedan & Camry & 1.193 unit & $6 \%$ \\
\hline & & & 162.329 unit & $100 \%$ \\
\hline
\end{tabular}

Sumber Data: Gaikindo

Berdasarkan data di tabel 1.2 produk Toyota yaris hanya mampu menjual sebanyak 38.482 unit atau hanya $24 \%$ dari berbagai segmen unggulan Toyota, berarti produk Yaris masih belum optimal dalam kualitas produknya sehingga belum mampu merajai penjualan di tanah air.
Sehingga perusahaan harus menciptakan produk untuk memenuhi kebutuhan dan keinginan konsumen.Untuk bisa memuaskan kebutuhan dan keinginan konsumen, maka perusahaan harus memiliki pengetahuan yang luas mengenai perilaku pembelian konsumen 
sasarannya. Dalam perkembangan konsep pemasaran mutakhir, konsumen ditempatkan sebagai pusat perhatian. Dalam proses keputusan pembelian memerlukan suatu upaya dari perusahaan agar produknya dapat sampai ke tangan konsumen, paling tidak perusahaan tersebut berusaha untuk mengubah perilaku konsumen dari rasa ingin tahu mengenai produk yang ditawarkan perusahaan menjadi rasa tertarik, bahkan dari rasa tertarik tersebut meningkat sampai pada adanya keinginan untuk memiliki produk sehingga konsumen tersebut akan mengambil keputusan pembelian terhadap produk yang ditawarkan oleh perusahaan.

Dalam perkembangannya semenjak diluncurkannya produk ini, konsumen menyambutnya dengan baik, hal ini terbukti dengan adanya beberapa konsumen yang melakukan pemesanan sebelum produk ini diluncurkan. Berbekal keyakinan dan didukung oleh Brand Image Toyota yang baik, pihak Toyota menargetkan YARIS mampuj menguasai pangsa pasar lebih baik ketimbang para pesaing yang sudah ada di pasar, YARIS memiliki empat varian : J, E, S,TRD Sportivo. Transmisi manual merupakan standar bagi semua varian, sementara transmisi otomatis hanya sedia untuk tipe $\mathrm{S}$ dan TRD Sportivo.

Dengan banyaknya jenis kendaraan yang sama yang diproduksi oleh para pesaing yang masing-masing mempunyai keunggulan. Toyota pada segmen kendaraan serba guna mulai mengandalkan pada Toyota YARIS selain mengandalkan kendaraan model yang lain. Dengan adanya produk baru dari produsen pesaing tentulah merasa pasarnya tersaing sehingga Toyota harus benar-benar memperhatikan kualitas produknya supaya bisa tetap bersaing dengan perusahaan otomotif yang lain.

Dalam proses keputusan pembelian terdapat dua faktor yang mempengaruhi yaitu faktor internal maupun eksternal. Faktor internal merupakan faktor yang berasal dari dalam salah satunya adalah psikologi konsumen, sedangkan faktor eksternal merupakan faktor dari luar yaitu pemasaran produk. Perusahaan harus dapat melakukan kegiatan pemasaran yang meliputi penentuan produk yang akan dijual dengan memperhatikan kebutuhan konsumen, penentuan harga yang sebanding dengan nilai yang ditawarkan, pendistribusian produk ke pasaran, dan strategi mengomunikasikan produk kepada masyarakat, sehingga dapat merangsang konsumen untuk melakukan pembelian.

PT.Toyota Wijaya Lestari Dago perlu memperhatikan keputusan pembelian yang dilakukan konsumen yang berorientasi pada ekspektasi konsumen dengan menetapkan keinginan dan kebutuhan konsumen sehingga PT.Toyota Wijaya Lestari Dago dapat mengembangkan strategi yang di rancang untuk mengedukasi konsumen mengenai kualitas utama sebuah produk, membujuk konsumen untuk melakukan pembelian.

Melalui riset ini akan dianalisis apakah kualitas produk dapat mempengaruhi keputusan konsumen dalam membeli mobil Toyota Yaris. Ketertarikan pemilihan merek Toyota Yaris dikarenakan produk mobil Toyota Yaris ini mengalami penurunan dan 
penaikan unit penjualan pada tahun 2014 sampai dengan tahun 2016.

Berikut adalah data penjualan berbagai segmen mobil Toyota yang ada di bandung :

Tabel 3. Data Penjualan Mobil Toyota Berbagai Segmen Di Bandung, Tahun 2014-2016 (Unit)

\begin{tabular}{|l|r|r|r|}
\hline Type & \multicolumn{1}{|c|}{2014} & \multicolumn{1}{c|}{2015} & \multicolumn{1}{c|}{2016} \\
\hline $\begin{array}{l}\text { Toyota } \\
\text { Avanza }\end{array}$ & 18.573 & 20.428 & 23.876 \\
\hline $\begin{array}{l}\text { Toyota } \\
\text { Yaris }\end{array}$ & 7.774 & 5.398 & 8.209 \\
\hline $\begin{array}{l}\text { Toyota } \\
\text { Camry }\end{array}$ & 99 & 113 & 127 \\
\hline
\end{tabular}

Sumber Data: $\underline{\text { www.gaikindo }}$

Pada tabel 1.4 data penjualan mobil Toyota Yaris di Bandung pada tahun 2014 sampai tahun 2015 mengalami penurunan, sedangkan di berbagai segmen yang lain Toyota Avanza dan Toyota Camry dari tahun 2014 sampai 2016 mengalami kenaikan penjualan. Untuk mobil Toyota Avanza dan Camry tidak mengalami perubahan dalam segi desain dan fitur, sedangkan penurunan penjualan pada tahun 2015 yang terjadi pada Toyota Yaris dikarenakan PT Toyota Astra Motor merencanakan peluncuran produk baru Toyota Yaris yang menyebabkan konsumen menahan untuk lebih menunggu produk Toyota Yaris yang baru. Pada tahun 2014 merupakan transisi dikarenakan produk Toyota Yaris terbaru launching pada bulan April 2014. Toyota Yaris saat ini merupakan generasi ketiga, bila dibandingkan dengan generasi pertana dan kedua, pada generasi ketiga ini terjadi perubahan besar-besaran dari sisi interior dan eksterior namun untuk mesin masih menggunakan tipe mesin yang sama yaitu 1NZ-FE.

Dari sisi dimensi all New Yaris berubah drastis menjadi lebih pendek dan lebih panjang. Dapat dikatakan Yaris menjadi mobil hatcback namun cita rasa sedan. Tampilan eksterior All New Yaris model terbaru lebih sporty dengan keen look design dimana pada grille depan berbentuk Trapezoidal yang lebih agresif. Bentuk headlamp lebih menyempit pada bagian ujung. Dari sisi interior All New Yaris semua tipe kini dilengkapi dengan audio unit layar sentuh dengan ukuran 5.9 inch. Dengan berbagai fitur menarik yang dimiliki oleh audio antara lain Radio, Voice Command, Air Gesture, Wi-Fi, DLNA, Toyota Move.

Bila dibandingkan dengan Toyota Yaris sebelumnya, All New Yaris lebih menarik perhatian konsumen dengan kualitas yang lebih baik juga teknologi yang dimiliki All New Yaris tidak heran penjualan All New Yaris pada tahun 2015 mengalami penaikan kembali.

Begitu pula yang terjadi di perusahaan PT. Toyota Wijaya Lestari Dago, selama beberapa tahun terakhir PT.Toyota Wijaya Lestari Dago mengalami penurunan penjualan hal tersebut menjadikan tidak stabilnya penjualan selama beberapa tahun terakhir. Penurunan penjualan yang terjadi pada PT.Toyota Wijaya Lestari Dago diindikasikan oleh banyaknya persaingan yang bergerak dibidang industri yang sama, yang mengakibatkan tingkat penjulan semakin menurun karena konsumen tidak melakukan pembelian kembali. Apabila keadaan ini 
terus berlanjut, maka akan mempengaruhi kinerja perusahaan dan akan berpengaruh pada dapat bertahan atau tidaknya usaha tersebut. Dengan begitu PT.Toyota Wijaya Lestari Dago harus melakukan strategi pemasaran yang berorentiasi pada kebutuhan pelanggan dengan memenuhi apa yang dibutuhkan dan diinginkan oleh konsumen sehingga dapat meningkatkan tingkat pembelian Toyota Yaris.

Tabel 4. Data Penjualan Mobil Toyota berbagai segmen di Wijaya Toyota Dago, Tahun 2014-2016 (Unit)

\begin{tabular}{|l|r|r|r|}
\hline Type & 2014 & \multicolumn{1}{|c|}{2015} & \multicolumn{1}{c|}{2016} \\
\hline $\begin{array}{l}\text { Toyota } \\
\text { Avanza }\end{array}$ & 600 & 690 & 786 \\
\hline $\begin{array}{l}\text { Toyota } \\
\text { Yaris }\end{array}$ & 85 & 78 & 88 \\
\hline $\begin{array}{l}\text { Toyota } \\
\text { Camry }\end{array}$ & 12 & 16 & 20 \\
\hline
\end{tabular}

Sumber Data : Wijaya Toyota Dago
Berdasarkan data penjualan PT.Toyota Wijaya Lestari Dago berhasil membukukan penjualan Toyota Yaris sebanyak 85 unit pada Tahun 2014 dan berhasil membukukan penjualan unit pada tahun 2015 sedangkan pada tahun 2016 mampu menjual 88 unit, terjadi penurunan dan kenaikan penjualan. Sedangkan untuk merek Toyota Avanza dan Camry tiap tahun selau mengalami kenaikan penjualan. Tabel 1.5 menunjukan naik dan turunnya penjualan Yoyota Yaris di Wijaya Toyota Dago.

Perubahan lingkungan yang begitu cepat menuntut perusahaan untuk beradaptasi secara cepat pula dengan melakukan perbaikan terus menerus. Dalam melakukan perubahan, perusahaan berusaha menciptakan nilai lebih bagi konsumen melalui penciptaan produk yang berkualitas.

Berikut disampaikan kuisioner pendahuluan kualitas produk Toyota Yaris :

Tabel 5. Kuisioner Pendahuluan Kualitas Produk Toyota Yaris

\begin{tabular}{|c|l|l|l|l|l|l|c|c|}
\hline $\begin{array}{c}\text { N } \\
\mathbf{0}\end{array}$ & \multicolumn{1}{|c|}{ Dimensi } & $\begin{array}{l}\text { Pernyat } \\
\text { aan }\end{array}$ & SS & S & KS & TS & STS & $\begin{array}{l}\text { Konsu } \\
\text { men }\end{array}$ \\
\hline 1 & $\begin{array}{l}\text { Kinerja(performa } \\
\text { nce) }\end{array}$ & $\begin{array}{l}\text { Toyota } \\
\text { Yaris } \\
\text { memilik } \\
\text { i } \\
\text { perform } \\
\text { a yang } \\
\text { memuas } \\
\text { kan }\end{array}$ & 10 & 8 & 6 & 4 & 2 & 30 \\
\hline $\begin{array}{l}\text { Keistimewaan(fe } \\
\text { atures })\end{array}$ & $\begin{array}{l}\text { Toyota } \\
\text { Yaris } \\
\text { memilik } \\
\text { i } \\
\text { features } \\
\text { yang }\end{array}$ & 13 & 10 & 3 & 3 & 1 & 30 \\
\hline
\end{tabular}




\begin{tabular}{|c|c|c|c|c|c|c|c|}
\hline & bagus & & & & & & \\
\hline $\begin{array}{l}\text { Kehandalan(relia } \\
\text { bility) }\end{array}$ & $\begin{array}{l}\text { Toyota } \\
\text { Yaris } \\
\text { memilik } \\
\text { i } \\
\text { kehanda } \\
\text { lan yang } \\
\text { baik }\end{array}$ & 11 & 9 & 4 & 3 & 3 & 30 \\
\hline $\begin{array}{l}\text { Kesesuaian } \\
\text { dengan } \\
\text { spesifikasi(confo } \\
\text { rmance to } \\
\text { specifications) }\end{array}$ & $\begin{array}{l}\text { Toyota } \\
\text { Yaris } \\
\text { memilik } \\
\text { i } \\
\text { kesesuai } \\
\text { an } \\
\text { dengan } \\
\text { spesifika } \\
\text { si }\end{array}$ & 9 & 11 & 3 & 4 & 3 & 30 \\
\hline $\begin{array}{l}\text { Daya } \\
\text { tahan(durability) }\end{array}$ & $\begin{array}{l}\text { Toyota } \\
\text { Yaris } \\
\text { memilik } \\
\text { i daya } \\
\text { tahan } \\
\text { yang } \\
\text { baik }\end{array}$ & 15 & 8 & 4 & 2 & 1 & 30 \\
\hline $\begin{array}{l}\text { Estetika(asthethi } \\
\text { c) }\end{array}$ & $\begin{array}{l}\text { Toyota } \\
\text { Yaris } \\
\text { memilik } \\
\text { i estetika } \\
\text { yang } \\
\text { enak } \\
\text { dipanda } \\
\text { ng }\end{array}$ & 12 & 10 & 5 & 2 & 1 & 30 \\
\hline Jumlah & & 70 & 56 & 25 & 18 & 11 & 180 \\
\hline Bobot/skor & & 350 & 224 & 75 & 36 & 11 & 696 \\
\hline Persentase & & $\begin{array}{c}50,28 \\
7 \%\end{array}$ & $\begin{array}{c}32,18 \\
4 \%\end{array}$ & $\begin{array}{c}10,77 \\
6 \%\end{array}$ & $\begin{array}{l}5,17 \\
2 \% \\
\end{array}$ & $\begin{array}{c}1,58 \\
0 \% \\
\end{array}$ & $100 \%$ \\
\hline
\end{tabular}

Sumber data olahan kuisioner pendahuluan 
Berdasarkan kuisioner pendahuluan dari kualitas produk mobil Yaris dapat dilihat bahwa Toyota Yaris memiliki kualitas yang baik dengan $82 \%$, tetapi keputusan pembeliannya belum optimal karena masih ada konsumen yang menyebut kualitas produk Toyota Yaris kurang baik sebanyak $18 \%$. Kuisioner tersebut dapat menjadi gambaran awal bagaimana kualitas produk Toyota Yaris di mata konsumen.

\section{KERANGKA TEORITIS \& HIPOTESIS \\ Keputusan Pembelian}

Keputusan pembelian konsumen terhadap suatu produk pada dasarnya erat kaitannya dengan perilaku konsumen. Perilaku konsumen merupakan unsur penting dalam kegiatan pemasaran suatu produk yang perlu diketahui oleh perusahaan, karena perusahaan pada dasarnya tidak mengetahui mengenai apa yang ada dalam pikiran seorang konsumen pada waktu sebelum, sedang, dan setelah melakukan pembelian produk tersebut.

Adanya kecenderungan pengaruh produk, pelayanan, dan lokasi terhadap keputusan pembelian yang dilakukan oleh konsumen tersebut, mengisyaratkan bahwa manajemen perusahaan perlu mempertimbangkan aspek perilaku konsumen, terutama proses pengambilan keputusan pembeliannya.

Keputusan pembelian merupakan suatu proses pengambilan keputusan akan pembelian yang mencakup penentuan apa yang akan dibeli atau tidak melakukan pembelian dan keputusan itu diperoleh dari kegiatankegiatan sebelumnya (Sofjan Assauri,2004:141).
Keputusan pembelian adalah sebuah pendekatan penyelesaian masalah pada kegiatan manusia untuk membeli suatu barang atau jasa dalam memenuhi keinginan dan kebutuhannya yang terdiri dari pengenalan kebutuhan dan keinginan, pencarian informasi, evaluasi terhadap alternatif pembelian, keputusan pembelian, dan tingkah laku setelah pembelian (Basu Swasta dan T Hani Handoko,2000:15).

Sedangkan menurut Philip Kotler (2000:251-252), yang dimaksud dengan keputusan pembelian adalah suatu proses penyelesaian masalah yang terdiri dari menganalisa atau pengenalan kebutuhan dan keinginan, pencarian informasi, penilaian sumber-sumber seleksi terhadap alternatif pembelian, keputusan pembelian, dan perilaku setelah pembelian.

Dari pengertian keputusan pembelian di atas dapat disimpulkan bahwa keputusan pembelian adalah perilaku pembelian seseorang dalam menentukan suatu pilihan produk untuk mencapai kepuasan sesuai kebutuhan dan keinginan konsumen yang meliputi pengenalan masalah, pencarian informasi, evaluasi terhadap alternatif pembelian, keputusan pembelian, dan perilaku setelah pembelian.

\section{A. Tahap-tahap dalam Proses Keputusan Pembelian}

Menurut Basu Swasta dan T Hani Handoko (2000:107-111), proses pengambilan keputusan pembelian suatu produk dapat digambarkan dalam bentuk proses kegiatan pembelian dengan tahapan sebagai berikut : 


\section{Gambar 1. Tahap-tahap Keputusan Pembelian}

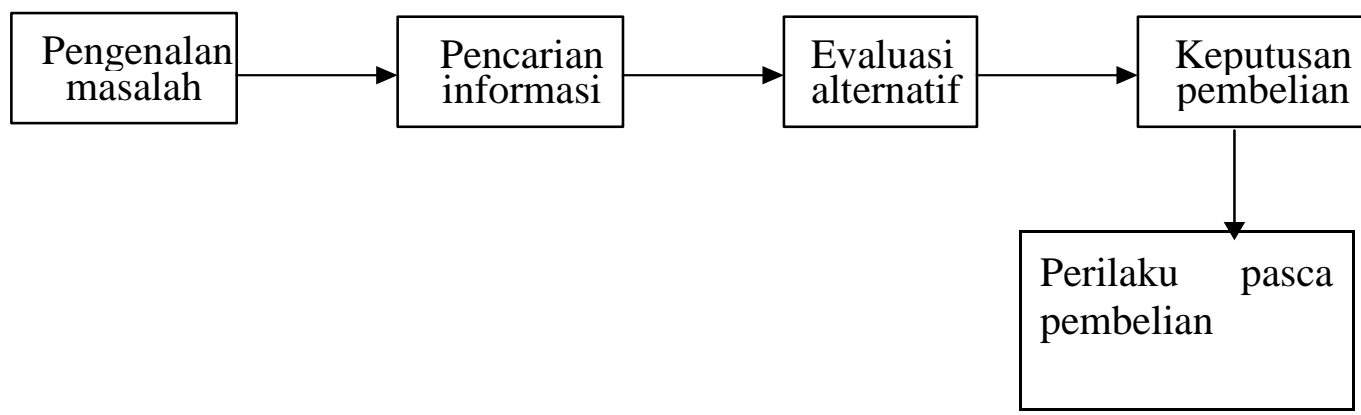

1. Pengenalan masalah

Proses pembelian dimulai ketika pembeli mengenal suatu masalah atau kebutuhan. Pengenalan kebutuhan ini ditujukan untuk mengetahui adanya kebutuhan dan keinginan yang belum terpenuhi dan terpuaskan. Jika kebutuhan tersebut diketahui, maka konsumen akan segera memahami adanya kebutuhan yang belum segera dipenuhi atau masih bisa ditunda pemenuhannya, serta kebutuhan yang sama-sama harus segera dipenuhi. Pengenalan masalah adalah suatu proses yang komplek yang dapat diuraikan sebagai berikut:

a. Proses ini melibatkan secara bersama-sama banyak variabelvariabel termasuk pengamatan, proses belajar, sikap, karakteristik kepribadian dan macam-macam kelompok sosial dan referensi yang mempengaruhinya;

b. Proses pengenalan masalah merupakan suatu proses yang lebih kompleks dari penganalisaan motivasi. Walaupun proses tersebut melibatkan motif-motif pembelian, tetapi selain itu melibatkan juga sikap, konsep diri, dan pengaruhpengaruh lain;

c. Proses ini melibatkan juga proses perbandingan dan pembobotan yang kompleks terhadap macammacam kebutuhan yang relatif penting, sikap tentang bagaimana menggunakan sumber keuangan yang terbatas untuk berbagai alternatif pembelian, dan sikap tentang kualitatif dari kebutuhan yang harus dipuaskan. (Basu Swasta dan $T$ Hani Handoko,2000:107-108)

2. Pencarian Informasi

Seseorang yang tergerak oleh stimulus akan berusaha mencari lebih banyak informasi yang terlibat dalam pencarian akan kebutuhan. Pencarian merupakan aktivitas termotivasi dari pengetahuan yang tersimpan dalam ingatan dan perolehan informasi dari lingkungan. Sumber informasi konsumen terdiri atas empat kelompok, yaitu:

a. Sumber pribadi meliputi keluarga, teman, tetangga, kenalan; 
b. Sumber komersial meliputi iklan, tenaga penjual, pedagang perantara, pengemasan;

C. Sumber umum meliputi media massa, organisasi ranting konsumen;

d. Sumber pengalaman meliputi penanganan, pemeriksaan, penggunaan produk.

3. Evaluasi alternative

$$
\text { Evaluasi alternatif }
$$
merupakan proses di mana suatu alternatif pilihan disesuaikan dan dipilih untuk memenuhi kebutuhan konsumen. Konsep dasar dalam proses evaluasi konsumen terdiri atas empat macam:

a. Konsumen berusaha memenuhi kebutuhan;

b. Konsumen mencari manfaat tertentu dari solusi produk;

c. Konsumen memandang setiap produk sebagai kumpulan atribut dengan kemampuan yang berbedabeda dalam memberikan manfaat yang dicari dalam memuaskan kebutuhan;

d. Konsumen mempunyai sifat yang berbeda-beda dalam memandang atributatribut yang dianggap relevan dan penting. Konsumen akan memberikan perhatian besar pada atribut yang memberikan manfaat yang dicarinya (Philip Kotler,2000:252-253)

4. Keputusan Membeli

Keputusan untuk membeli disini merupakan proses dalam pembelian yang nyata. Jadi, setelah tahap-tahap di muka dilakukan, maka konsumen harus mengambil keputusan apakah membeli atau tidak. Konsumen mungkin juga akan membentuk suatu maksud membeli dan cenderung membeli merek yang disukainya. Namun, ada faktorfaktor lain yang ikut menentukan keputusan pembelian, yaitu sikap orang lain dan faktor-faktor situasional yang tidak terduga. Bila konsumen menentukan keputusan untuk membeli konsumen akanmenjumpai keputusan yang harus diambil menyangkut jenis produk, merek, penjual, kuantitas, waktu pembelian, dan cara pembayarannya.

5. Perilaku setelah pembelian

Tugas pemasar tidak berakhir saat produk dibeli,
melainkan berlanjut hingga periode pasca pembelian. Setelah pembelian produk terjadi, konsumen akan mengalami suatu tingkat kepuasan atau ketidakpuasan. Kepuasan atau ketidakpuasan pembeli dengan produk akan mempengaruhi tingkah laku berikutnya.

Konsumen yang merasa puas akan memperlihatkan peluang membeli yang lebih tinggi dalam kesempatan berikutnya. Konsumen yang merasa puas akan cenderung mengatakan sesuatu yang serba baik tentang produk yang bersangkutan kepada orang lain. Apabila konsumen dalam melakukan pembelian tidak merasa puas dengan produk yang telah dibelinya ada dua kemungkinan yang akan dilakukan 
oleh konsumen. Pertama, dengar4. Pembeli (buyer) yaitu individu yang meninggalkan atau konsumen melakukan transaksi pembelian tidak mau melakukan pembelian sesungguhnya;

ulang. Kedua, ia akan mencar5. Pemakai (user) yaitu individu yang informasi tambahan mengenai mempergunakan produk atau jasa yang produk yang telah dibelinya untuk dibeli.

menguatkan pendiriannya mengapa ia memilih produk itu sehingga ketidakpuasan tersebut dapat dikurangi.

B. Peranan dalam Proses Keputusan Pembelian

Dalam keputusan membeli barang, konsumen seringkali melibatkan beberapa pihak dalam proses pertukarar 2 . atau pembeliannya. Umumnya ada lima macam peranan yang dapat dilakukan seseorang. Ada kalanya kelima peran in 3 . dipegang oleh satu orang, namun seringkali peran tersebut dilakukan oleh beberapa orang.

Menurut Basu swasta dan T Hani Handoko (2000:13) menjelaskan ada lima macam peranan dalam perilaku konsumen. Kelima peranan tersebut meliputi:

1. Pengambil inisiatif (initiator) yaitu individu dalam keluarga yang mempunyai inisiatif pembelian barang atau jasa tertentu atau mempunyai keinginan dan kebutuhan tetapi tidak mempunyai wewenang untuk melakukan sendiri;

2. Orang yang mempengaruhi (influencer) yaitu individu yang mempengaruhi keputusan untuk membeli baik secara disengaja atau tidak disengaja;

3. Pembuat keputusan (decider) yaitu individu yang memutuskan apakah akan membeli atau tidak, apakah yang akan dibeli, bagaimana membelinya, kapan dan di mana membelinya;

Sedangkan Philip Kotler (2000:246) membedakan lima peran yang dimainkan orang dalam keputusan pembelian sebagai berikut:

1. Pencetus ide yaitu seseorangyang pertama kali mengusulkan ide untuk membeli suatu produk atau jasa tertentu, Pemberi pengaruh yaitu seseorang yang pandangan atau pendapatnya mempengaruhi keputusan pembelian,

Pengambil keputusan yaitu seseorang yang memutuskan setiap komponen dalam keputusan pembelian,

4. Pembeli yaitu seseorang yang melakukan pembelian yang sebenarnya,

Pemakai yaitu seseorang yang mengkonsumsi produk tersebut.

\section{Kualitas Produk Kualitas}

Mutu (kualitas) dalam kerangka ISO 9000 didefinisikan sebagai "ciri dan karakter menyeluruh dari suatu produk atau jasa yang mempengaruhi kemampuan produk tersebut untuk memuaskan kebutuhan tertentu". Hal ini berarti bahwa kita harus dapat mengidentifikasikan ciri dan karkter produk yang berhubungan dengan mutu dan kemudian membuat suatu dasar tolok ukur dan cara pengendaliannya.

Definisi ini jelas menekankan pada kepuasan pelanggan atau pemakai produk. Dalam suatu proyek gedung, pelanggan dapat berarti pemberi tugas, penyewa gedung atau masyarakat 
pemakai. Misalnya dari segi disain, kepuasan dapat diukur dari segi estetika, pemenuhan fungsi, keawetan bahan, keamanan, dan ketepatan waktu. Sedangkan dari segi pelaksanaan, ukurannya adalah pada kerapihan penyelesaian, integritas (sesuai gambar dan spesifikasi) pelaksanaan, tepatnya waktu penyerahan dan biaya, serta bebas cacat.

\begin{tabular}{llr}
\multicolumn{2}{c}{ Manajemen Mutu } & (kualitas) \\
adalah aspek-aspek dari & fungsi \\
manajemen $\quad$ keseluruhan & yang
\end{tabular}
menetapkan dan menjalankan kebijakan mutu suatu perusahaan/organisasi. Dalam rangka mencukupkan kebutuhan pelanggan dan ketepatan waktu dengan anggaran yang hemat dan ekonomis, seorang manager proyek harus memasukkan dan mengadakan pelatihan management kualitas. Hal hal yang menyangkut kualitas yang di maksud diatas adalah :

$$
\begin{aligned}
& \checkmark \text { Produk / pelayanan / } \\
& \text { proses pelaksanaan. } \\
& \checkmark \text { Proses management } \\
& \text { proyek itu sendiri. }
\end{aligned}
$$

Didalam tuntutan zaman, dan dalam era persaingan bebas, kita harus banyak belajar tentang hal hal yang menyangkut proses manajemen dalam lingkungan kerja, terutama tentang pentingnya sistem dan realisasinya dalam proyek di lapangan.

\section{Faktor}

Konsep kualitas itu sendiri sering dianggap sebagai ukuran relatif kebaikan suatu produk atau jasa yang terdiri atas kualitas desain dan kualitas kesesuaian. Kualitas desain merupakan fungsi spesifikasi produk, sedangkan kualitas kesesuaian adalah suatu ukuran seberapa jauh suatu produk memenuhi persyaratan atau spesifikasi kualitas yang telah ditetapkan.

Konsep kualitas secara luas tidak hanya menekankan pada aspek hasil tetapi juga kualitas manusia dan kualitas prosesnya. Bahkan Stephen Uselac menegaskan bahwa kualitas bukan hanya mencakup produk dan jasa, tetapi juga meliputi proses, linkungan dan manusia.

\section{Macam Jenis}

Meskipun tidak ada defenisi mengenai kualitas yang diterima secara universal, dari defenisi-defenisi yang ada terdapat beberapa kesamaan, yaitu dalam elemenelemen sebagai berikut :

1. Kualitas meliputi usaha mamenuhi atau melebihi harapan pelanggan.

2. Kualitas mencakup produk, jasa, manusia, proses dan lingkungan.

3. Kualitas merupakan kondisi yang selalu berubah ( misalnya apa yang dianggap merupakan kualitas saat ini mungkin dianggap kurang berkualitas pada mendatang).

\section{Produk}

Setiap perusahaan akan berusaha untuk memenuhi kebutuhan dan keinginan konsumen dengan menyediakan produk yang ada. Produk ialah seperangkat aribut baik berwujud maupun tidak berwujud ,termasuk didalamnya masalah warna, harga, nama pabrik, nama baik toko yang menjual (pengecer), dan pelayanan pabrik serta pelayanan pengecer, yang diterima oleh pembeli guna memuaskan keinginannya (W.J.Stanton, 1981 : 192).

Produk adalah segala sesuatu yang ditawarkan produsen untuk diperhatikan, diminta, dicari, dibeli, 
digunakan atau dikonsumsi yang meliputi mutu/kualitas, pilihan yang ada (options), merek (brand names), pengemasan (packaging), macam (product items), ukuran (sizes), jenis (product lines), dan jaminan (Sofjan Assauri,2004:200). Selain itu, produk dapat pula didefinisikan sebagai persepsi konsumen yang dijabarkan melalui hasil produksinya. Secara lebih rinci, konsep produk total meliputi barang, kemasan, merek, label, dan jaminan (Fandy Tjiptono,2000:95). Yang dimaksud dengan produk dalam penelitian ini adalah barang yang ditawarkan oleh toko minimarket kepada konsumen atau calon konsumen yang meliputi kualitas produk, harga, kelengkapan produk, dan jaminan.

Dari beberapa definisi menurut para ahli dapat disimpulkan pengertian produk adalah barang berwujud atau tidak berwujud yang diciptakan oleh produsen yang mempunyai nilai untuk memenuhi kebutuhan konsumen.

\section{Klasifikasi Produk}

Di dalam strategi marketing mix, strategi produk merupakan unsur yang paling penting, karena dapat mempengaruhi strategi pemasaran yang lainnya. Tujuan utama strategi produk adalah untuk dapat mencapai sasaran pasar yang dituju dengan meningkatkan kemampuannya untuk mengatasi persaingan. Menurut Sofjan Assauri (2004:202) produk yang dibeli konsumen dapat dibedakan atas tiga tingkatan, yaitu:

1. Produk inti, merupakan inti atau dasar yang sesungguhnya dari produk yang ingin diperoleh oleh seorang pembeliatau konsumen dari produk tersebut.
2. Produk formal, merupakan bentuk, kualitas, dan kemasan yang menyertai produk tersebut.

3. Produk tambahan, merupakan tambahan produk formal dengan berbagai jasa yang menyertainya.

Di bidang pemasaran, produk dapat diklasifikasikan menurut dasar yang berbeda-beda. Berdasarkan berwujud tidaknya, produk dapat dibedakan menjadi dua kelompok utama yaitu barang dan jasa.

\section{Barang}

Barang merupakan produk yang berwujud fisik, sehingga bisa dilihat, diraba, disentuh, dirasa, dipegang, disimpan, dipindahkan, dan perlakuan fisik lainnya. Ditinjau dari aspek daya tahannya, terdapat dua macam barang, yaitu:

a. Barang tidak tahan lama, adalah barang berwujud yang biasanya habis dikonsumsi dalam satu atau beberapa kali pemakaian;

b. Barang tahan lama, merupakan barang berwujud yang biasanya bisa bertahan lama dengan banyak pemakaian (umur ekonomisnya untuk pemakaian normal adalah satu tahun atau lebih.

Barang konsumsi adalah barang yang dikonsumsi untuk kepentingan konsumen akhir sendiri (individu dan rumah tangga). Barang konsumsi dapat diklasifikasikan menjadi tiga golongan yaitu: 
a. Barang konvenien

Barang konvenien merupakan barang yang pada umumnya memiliki frekuensi pembelian tinggi (sering dibeli), dibutuhkan dalam waktu segera, dan hanya memerlukan usaha yang minimum, contoh: sabun, makanan, dan lain-lain.

\section{b. Barang shopping}

Barang shopping adalah barang-barang yang dalam proses pemilihan dan pembeliannya dibandingkan oleh konsumen di antara berbagai alternatif yang tersedia, contoh: alat-alat rumah tangga, pakaian.

\section{c. Barang special}

Barang spesial adalah barang yang mempunyai ciri khas, dan hanya dapat dibeli di tempat tertentu saja, contoh: barang-barang mewah (Basu Swasta, 1996:96-97).

2. Jasa

Jasa adalah sesuatu yang dapat diidentifikasi secara terpisah tidak berwujud, ditawarkan untuk memenuhi kebutuhan. Jasa dapat dihasilkan dengan menggunakan benda-benda berwujud atau tidak (William J.Stanton, 1981:529).

\section{Kualitas Produk}

Kualitas produk merupakan hal yang perlu mendapat perhatian utama dari perusahaan atau produsen mengingat kualitas produk berkaitan erat dengan masalah keputusan konsumen (Sofjan Assauri,2004:192). Kualitas produk berkaitan dengan masalah kepuasan konsumen yang merupakan tujuan dari kegiatan pemasaran yang dilakukan oleh perusahaan. Kualitas produk menunjukkan ukuran tahan lamanya produk itu, dapat dipercayainya produk tersebut, mudah mengoperasikan dan memeliharanya serta atribut yang lain yang dinilai konsumen.

A. Dimensi Kualitas Produk

Menurut tjiptono (2008), kualitas

mencerminkan semua dimensi penawaran produk yang menghasilkan manfaat (benefits) bagi pelanggan. Dimensi kualitas produk menurut Tjiptono (2008) adalah:

1. Kinerja (Perpormance), berhubungan dengan karakteristik operasi dasar dari sebuah produk.

2. Daya tahan (Durability), yang berarti berapa lama atau umur produk yang bersangkutan bertahan sebelum produk tersebut diganti.

3. Kesesuaian dengan Spesifikasi (Conformance to Specification), yaitu sejauh mana karakteristik operasi dasar dari sebuah produk memenuhi spesifikasi tertentu dari konsumen atau tidak ditemukannya cacat pada produk.

4. Fitur (Feature), adalah karakteristik yang dirancang untuk menyempurnakan fungsi produk atau ,menambah ketertarikan konsumen terhadap produk.

5. Reliabilitas (Reliability), adalah propabilitas bahwa produk akan bekerja dengan memuaskan atau tidak dalam periode waktu tertentu.

6. Estetika (Aesthetics), berhubungan dengan bagaimana penampilan produk.

7. Kesan kualitas (Perceived quality), sering dibilang merupakan hasil dari penggunaan pengukuran yang dilakukan secara tidak langsung karena terdapat kemungkinan bahwa konsumen tidak mengerti atau 
kekurangan informasi atas produk yang bersangkutan.

8. Service (Serviceability), meliputi kecepatan dan kemudahan untuk direparasi,serta kompetensi dan keramahtamahan staf layanan.

Dari penjelasan diatas dapat disimpulkan bahwa suatu dimensi kualitas merupakan syarat agar suatu nilai dari produk memungkinkan untuk bias memuaskan pelanggan sesuai harapan, adapun dimensi kualitas produk meliputi kinerja, estetika, keistimewaan, kehandalan, dan juga kesesuaian.

\section{METODE PENELITIAN Metode Studi}

Dalam melakukan penelitian ini, penulis menggunakan metode deskriptif. Mohammad Nazir (2003:54)25, medefinisikan sebagai berikut : Metode deskriptif adalah suatu metode dalam meneliti status kelompok manusia, suatu objek, suatu sistem pemikiran, ataupun suatu kelas peristiwa pada masa akan datang.

Tujuan dari penelitian deskriptif ini adalah untuk membuat deskripsi, gambaran atau lukisan secara sistematis, faktual dan akurat megenai fakta-fakta, sifat-sifat serta hubungan antar fenomena yang diselidiki. Dimana hubungan yang diteliti antara kualitas produk sebagai sebagai vaiabel $\mathrm{X}$ dan proses keputusan pembelian sebagai variabel Y.

\section{Populasi dan Sampel Penelitian}

\section{A. Populasi}

Populasi adalah wilayah generalisasi yang terdiri dari: obyek/ subyek yang mempunyai kualitas dan karakteristik tertentu yang ditetapkan oleh peneliti untuk dipelajari dan kemudian ditarik kesimpulannya (Sugiyono 2009 : 115). Adapun populasi dalam penelitian ini adalah konsumen/ pembeli mobil Toyota Yaris yang datang ke Wijaya Toyota Dago dalam satu tahun terakhir yaitu tahun 2016 berjumlah 88 orang.

B. Sampel dan Sampling

Sampling adalah objek yang diteliti yang dianggap mewakili seluruh populasi (Notoatmodjo, 2010). "Sampel adalah bagian dari jumlah dan karakteristik yang dimiliki oleh populasi tersebut" (Sugiyono, 2013:73). Pemilihan sampel dengan metode yang tepat dapat menggambarkan kondisi populasi yang sesungguhnya yang akurat dan dapat menghemat biaya penelitian secara efektif.

Populasi dalam penelitian ini adalah seluruh konsumen/ pembeli mobil Toyota Yaris di Wijaya Toyota dago Bandung. Jumlah sampel yang diambil, berdasarkan rumus Slovin, yang ditulis pada buku Husein Umar(2004) yaitu:

$$
n=\frac{N}{1+N_{e^{2}}}
$$

Dimana: $\mathrm{n}$ : ukuran sampel; $\mathrm{N}$ : ukuran populasi; e : kelonggaran (standar error) yang bisa ditolelir (5\%)

$$
\begin{aligned}
& n=\frac{88}{1+(88)(0,05)^{2}} \\
& n=\frac{88}{1,22} \quad n=72,13
\end{aligned}
$$


Dengan data yang diperoleh dari Wijaya Toyota dago tentang populasi penelitian, dimana konsumen/ pembeli mobil Toyota Yaris di Wijaya Toyota dago selama satu tahun, ditahun 2016 mencapai 88 unit, maka diperoleh sampel 72 orang. Pengambilan sampel menggunakan rancangan sampling nonprobabilitas dengan teknik sampling Accidental yaitu penentuan sampel secara acak, yaitu siapa saja yang kebetulan bertemu dengan peneliti dapat digunakan sebagai sampel. Penyebaran kuesioner dilakukan selama empat pekan terhadap 72 orang konsumen/ pembeli mobil Toyota Yaris di Wijaya Toyota Dago.

\section{Metode Analisis Data Uji Validitas}

Uji validitas dimaksudkan untuk mengetahui tingkat kevalidan suatu instrumen penelitian. Sebuah instrumen dikatakan valid apabila dapat mengungkap data dari variabel yang diteliti secara tepat. Tinggi rendahnya validitas instrumen menunjukan sejauh mana data yang terkumpul tidak menyimpang dari gambaran tentang validitas yang dimaksud.

Dalam pengujian validitas dari instrumen atau kuesioner, dalikukan perhitungan korelasi antara masingmasing pertanyaan dengan skor total, dengan menggunakan rumus teknik korelasi product moment yang sebelumnya dilakukan perangkingan terlebih dahulu, Sugiyono (2004:98)24, yaitu:

$\mathrm{r}=\frac{n \sum X Y-\left(\sum X\right)\left(\sum Y\right)}{\sqrt{\left\{n\left(\sum X\right)^{2}\right\}\left\{n \sum Y^{2}-\left(\sum Y\right)^{2}\right\}}}$

Keterangan:

$\begin{array}{cl}\underset{r}{\operatorname{moment}} & =\text { korelasi product } \\ \mathrm{X} & =\text { skor pernyataan } \\ \mathrm{Y} & =\text { skor total seluruh }\end{array}$

pernyataan

$\mathrm{n} \quad$ = jumlah responden

Setelah diketahui dari hasil perhitungan besarnya korelasi. Kemudian dibandingkan dengan tabel $r$ product moment dengan kriteria sebagai berikut:

Jika $r$ hitung $\geq r$ tabel, maka data tersebut valid

Jika $r$ hitung $<r$ tabel, maka data tersebut tidak valid

\section{Uji Realibilitas}

Selain memiliki tingkat validasi, alat ukur juga harus memiliki karakteristik realibilitas. Sugiyono menyatakan bahwa reliable berarti instrument tersebut bila digunakan beberapa kali untuk mengukur objek yang sama akan menghasilkan data yang sama. Uji realibilitas dilakukan dengan menggunakan metode alpha cronbach's yang diukur berdasarkan skala alpha cronbach's 0 sampai 1. Sugiyono menyatakan bahwa jika skala dikelompokan dalam 5 kelas dengan range yang sama maka ukuran kemantapan alpha dapat diinterpretasikan sebagai berikut:

1. Nilai alpha cronbach 0,00 s.d 0,20 berarti kurang reliable 
2. Nilai alpha cronbach 0,21 s.d 0,40 berati agak reliable

3. Nilai alpha cronbach 0,41 s.d 0,60 berarti cukup reliable

4. Nilai alpha cronbach 0,61 s.d 0,80 berarti reliable

5. Nilai alpha cronbach 0,81 s.d 1,00 berarti sangat reliable

\section{Uji Statistik}

\section{Uji Linieritas}

Menurut Imam Ghozali (2007: 115) Uji linearitas digunakan untuk melihat apakah spesifikasi model yang digunakan sudah benar atau tidak. Hal tersebut didukung oleh pendapat Purbayu Budi Santosa \& Ashari tentang asumsi linearitas : "asumsi ini menyatakan bahwa untuk persamaan regresi linier, hubungan antara variabel independen dan dependen harus linier". Uji linieritas dapat dilakukan dengan melihat gambar diagram pancar (scatter diagram) dengan kriteria bahwa apabila plot titik-titik mengikuti pola tertentu maka berarti tidak linier dan sebaliknya apabila plot titik-titik tidak mengikuti pola tertentu maka berarti linier.

Dasar pengambilan keputusan dalam uji liniearitas adalah:

1. Jika nilai probabilitas $>0,05$ maka hubungan antara variabel $\mathrm{X}$ dan variabel $Y$ adalah linear.

2. Jika nilai probabilitas $<0,05$ maka hubungan antara variabel $\mathrm{X}$ dan variabel $\mathrm{Y}$ adalah tidak liniear.

\section{Uji Normalitas}

Uji Normalitas bertujuan untuk menguji apakah dalam model regresi yang digunakan, variabel terikat, variabel bebas atau keduanya memiliki distribusi normal atau tidak. Model regresi yang baik adalah yang memiliki distribusi data normal atau penyebaran data statistik pada sumbu diagonal dari grafik distribusi normal (Ghozali, 2005).

Pengujian normalitas digunakan dengan melihat normal probability plot yang membandingkan distribusi kumulatif dari data sesungguhnya dengan distribusi kumulatif dari data normal. Sedangkan dasar pengambilan keputusan untuk uji normalitas data adalah (Ghozali, 2005):

- Jika data menyebar disekitar garis diagonal dan mengikuti arah garis diagonal atau grafik histogramnya menunjukkan distribusi normal, maka model regresi memenuhi asumsi normalitas.

- Jika data menyebar jauh dari diagonal dan atau tidak mengikuti arah garis diagonal atau grafik histogram tidak menunjukkan distribusi normal, maka model regresi tidak memenuhi asumsi normalitas.

\section{Analisis Regresi Sederhana}

Dalam penelitian ini penulis menggunakan metode regresi linier sederhana yaitu Analisa regresi digunakan untuk memprediksi seberapa jauh perubahan nilai variable dependent, bilai nilai variable independent di manipulasi atau dirubah-rubah atau di naik turunkan. Menurut sugiyono, Regresi linerar sederhana biasanya 
didasarkan pada hubungan fungsional ataupun kasual satu variable independent dengan satu variable dependent.

Persamaan umum regregsi linier sederhana adalah:

$$
\mathrm{Y}=\mathrm{a}+\mathrm{bx}
$$

Ket : $\quad \mathrm{Y}=$ Variabel dependen yaitu loyalitas pelangggan

$\mathrm{a}=$ harga $\mathrm{y}$ bila $\mathrm{X}=0$ (Konstanta)

$\mathrm{b}=$ angka koefisien regresi yang menunjukan angka peningkatan atau penurunan variable dependen yang didasarkan pada variabel independen.

$\mathrm{X}=$ variabel independen yaitu kepuasan pelanggan.

\section{ANALISIS DATA DAN PEMBAHASAN \\ Profil Responden}

Berdasarkan penyebaran kuesioner terhadap 72 orang konsumen diperoleh gambaran :

- identitas responden berdasarkan jenis kelamin, usia, status perkawinan, tingkat pendidikan konsumen Toyota Wijaya Dago.

- jenis kelamin responden yang paling banyak adalah pria dengan presentase $73,6 \%$ dibandingkan dengan responden wanita.

- responden dengan usia 36 - 45 Tahun berjumlah 31 orang atau 43,1\% lebih banyak dari usia responden lainnya.

- responden yang memiliki pendidikan S1 paling banyak dengan presentase $59,7 \%$ dibandingkan dari pendidikan lainnya

- responden paling banyak telah menikah dengan presentase $87,5 \%$ dibandingkan dengan responden yang belum kawin.

Statistik Deskriptif

Tabel 6. Deskriptif Statistik

\begin{tabular}{|l|c|c|}
\hline \multicolumn{1}{|c|}{ Variabel } & Responden & Rata-Rata \\
\hline Kualitas Produk & 72 & 3,92 \\
Keputusan & 72 & 3,28 \\
Pembelian & 72 & \\
Valid N (listwise) & & \\
\hline
\end{tabular}

Sumber : Hasil Perhitungan SPSS 17

Dari table diatas menunjukkan skor rata-rata variable Kualitas Produk lebih tinggi bila dibandingkan dengan variable lainnya, Tabel diatas juga menginformasikan bahwa variable Keputusan Pembelian mempunyai variasi paling rendah dibandingkan variable lainnya, Untuk memberikan gambaran yang lebih jelas mengenai makna hasil perhitungan statistic deskriptif diatas, selanjutnya dibandingkan dengan table criteria penafsiran kondisi variable penelitian pada masing-masing variable yang diteliti, Model yang dipakai mengadopsi model pengontrolan kualitas dari Suprapto,2001.

\section{Tabel 7. Hasil penafsiran kondisi} variabel penelitian

\begin{tabular}{|l|c|c|}
\hline \multicolumn{1}{|c|}{ Variabel } & $\begin{array}{c}\text { Rata- } \\
\text { rata }\end{array}$ & Kriteria \\
\hline Kualitas Produk & 3,92 & Baik/Tinggi \\
\hline $\begin{array}{l}\text { Keputusan } \\
\text { Pembelian }\end{array}$ & 3,28 & $\begin{array}{c}\text { Cukup } \\
\text { Baik/Cukup } \\
\text { Tinggi }\end{array}$ \\
\hline
\end{tabular}

Sumber: Olahan Data tahun 2017 
Berdasarkan table diatas, terlihat bahwa variabel Kualitas Produk, dikategorikan tinggi, sedangkan variabel Keputusan Pembelian dikategorikan cukup tinggi

Analisis Verifikatif

\section{Uji Persyaratan Pengolahan Data}

Sebelim pengujian hipotesis penelitian, terlebih dahulu dilakukan pengujian persyaratan pengolahan data. Uji persyaratan pengolahan data untuk uji hipotesis dan analisis data meliputi uji normalitas dan uji linieritas.

\section{Uji Linieritas}

Uji Linieritas, dilakukan untuk mengetahui kenormalan distribusi data, untuk masing-masing variabel penelitian

\section{Scatterplot}

Dependent Variable: Pembelian

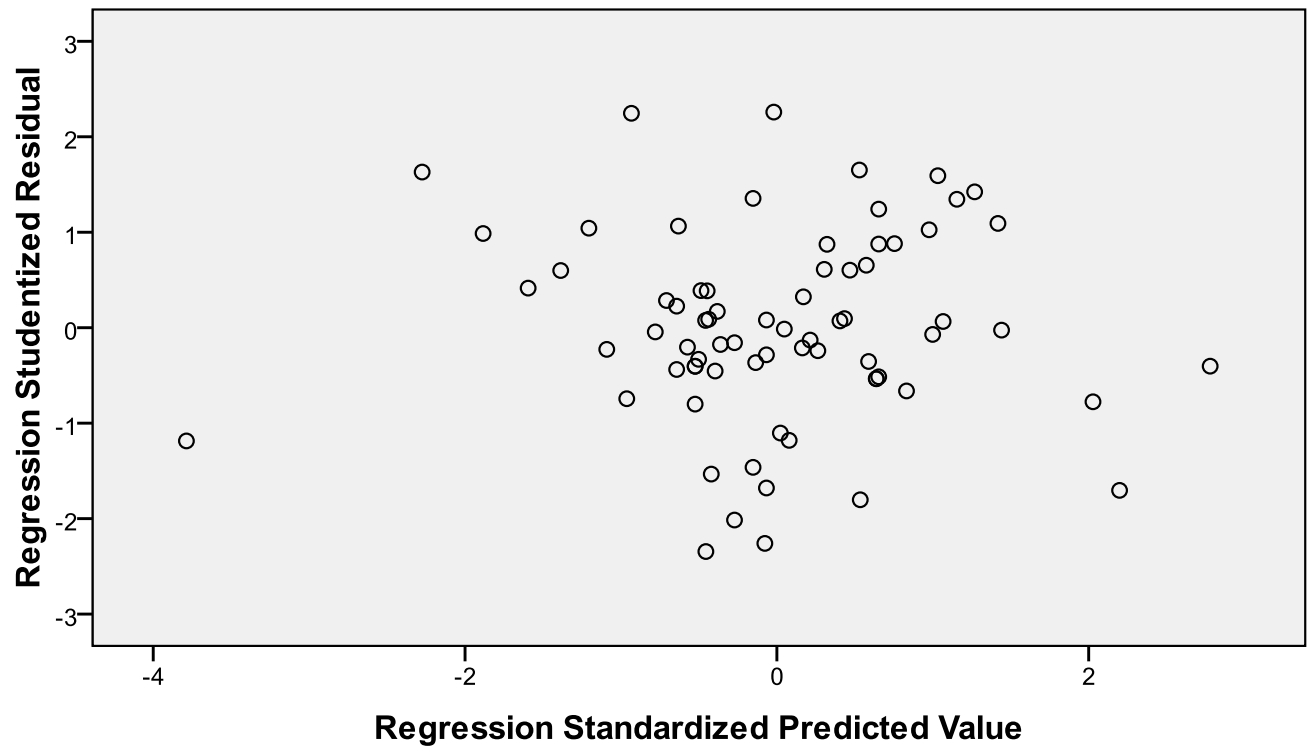

Gambar 2. Scatterplot

Sumber : Data Olahan dari

Berdasarkan hasil pengujian pada sumbu Y. Hal ini dapat heteroskedastisitas yang dapat dilihat disimpulkan bahwa tidak terjadi pada gambar 4.1, pada bagian diagram heteroskedastisitas pada model regresi. scatterplot nampak bahwa tidak ada pola yang jelas dan teratur serta titik-titik menyebar diatas dan dibawah angka 0

\section{Uji Normalitas}


Uji normalitas, dilakukan untuk untuk masing-masing variabel penelitian. mengetahui kenormalan distribusi data,

\section{Histogram}

\section{Dependent Variable: Pembelian}

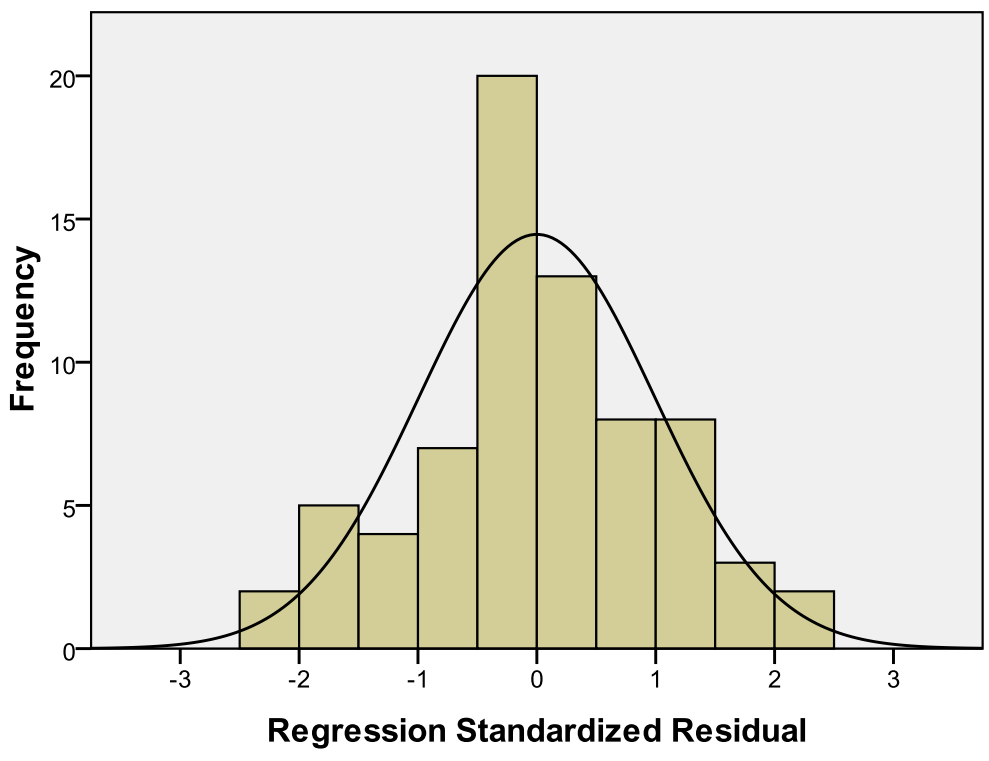

Mean $=-7.45 \mathrm{E}-15$

Std. Dev. $=0.993$
$N=72$

Gambar 3. Histogram

Sumber : Data Olahan

Berdasarkan hasil pengujian yang dapat dilihat pada grafik histogram (Gambar 4.2) dapat disimpulkan bahwa distribusi data mendekati normal karena tidak ada penyimpangan yang cukup mencolok dari kurva maupun garis normal. Sehingga dapat dikatakan bahwa asumsi normalitas terpenuhi

\section{Analisis Data}

Sebelum melakukan analisis data statistik, penulis mencoba memaparkan analisa yang berkaitan dengan hasil scoring dari tiap variabel dalam penelitian ini yakni variabel Kualitas Produk (X) terhadap Keputusan Pembelian (Y). Analisis data pada penelitian ini menggunakan metode atau teknik analisis regresi linier sederhana. Analisis regresi merupakan teknik statistik yang berguna untuk memeriksa dan memodelkan hubungan di antar variabel-variabel. Dimana penerapan regresi tersebut umumnya dikaitkan dengan studi ketergantungan suatu variabel (variabel terikat) pada variabel 
lainnya (variabel bebas). Sedangkan analisis regresi linier sederhana secara umum digunakan untuk menganalisis hubungan antara satu variabel bebas.

Untuk mengetahui pengaruh Kualitas Produk (X) terhadap Keputusan Pembelian (Y), dengan bantuan software
SPSS 17 for Windows, maka hasil dapat dilihat pada tabel berikut:

Tabel 8. Koeffisien

Coefficients $^{\mathrm{a}}$

\begin{tabular}{|c|c|c|c|c|c|c|}
\hline \multirow{2}{*}{\multicolumn{2}{|c|}{ Model }} & \multicolumn{2}{|c|}{$\begin{array}{l}\text { Unstandardized } \\
\text { Coefficients }\end{array}$} & \multirow{2}{*}{$\begin{array}{c}\begin{array}{c}\text { Standardized } \\
\text { Coefficients }\end{array} \\
\text { Beta }\end{array}$} & \multirow[b]{2}{*}{$\mathrm{t}$} & \multirow[b]{2}{*}{ Sig. } \\
\hline & & B & Std. Error & & & \\
\hline & (Constant) & 9.365 & 3.309 & & 2.830 & .006 \\
\hline & Produk & .917 & .078 & .917 & 19.268 & .000 \\
\hline
\end{tabular}

a. Dependent Variable: Pembelian

Dari tabel di atas pengujian menunjukkan persamaan regresi dengan persamaan regresi sebagai berikut:

$$
Y=\beta_{0}+\beta X+\varepsilon
$$

Yang diperoleh adalah sebagai berikut:

$$
Y=9.365+0,917 X
$$

Dari persamaan regresi diatas dapat dilihat bahwa koefisien regresi $\left(\beta_{\mathrm{i}}\right)$ untuk variabel Kualitas Produk (X) bertanda positif, artinya variabel tersebut berpengaruh positif terhadap Keputusan Pembelian (Y).

Variabel Kualitas Produk (X) memiliki nilai koefisien regresi $\left(b_{i}\right)$ sebesar 0,917. Hal ini menunjukkan bahwa setiap peningkatan variabel Kualitas Produk (X) satu satuan nilai akan meningkatkan Keputusan Pembelian (Y) 0,917 satuan nilai, dengan asumsi variabel lainnya nol.
Untuk mengetahui seberapa besar pengaruh variabel Kualitas Produk (X) terhadap Keputusan Pembelian (Y) maka akan dilakukan pengujian terhadap garis regresi tersebut melalui hipotesis.

\section{Koefisien Determinasi}

Tabel 9. Model Summary

\begin{tabular}{|l|r|r|r|r|}
\multicolumn{5}{|c|}{ Model Summary $^{\text {b }}$} \\
\begin{tabular}{|l} 
Mod \\
el
\end{tabular} & $\mathrm{R}$ & $\begin{array}{c}\mathrm{R} \\
\text { Square }\end{array}$ & $\begin{array}{c}\text { Adjusted } \\
\text { R Square }\end{array}$ & $\begin{array}{c}\text { Std. Error } \\
\text { of the } \\
\text { Estimate }\end{array}$ \\
\hline 1 & $.917^{\mathrm{a}}$ & .841 & .839 & 2.72309 \\
\hline
\end{tabular}

Sumber : Data Olahan
a. Predictors: (Constant), Produk
b. Dependent Variable: Pembelian

Koefisien

Determinasi merupakan koefisien yang digunakan untuk mengetahui besarnya kontribusi variabel independen terhadap perubahan 
variabel dependen, sesuai dengan hasil perhitungan total pengaruh langsung diperoleh $84,1 \%$ dengan demikian kontribusi $15,9 \%$ merupakan kontribusi variabel lain yang tidak diteliti

\section{Pengujian Hipotesis}

Setelah diperoleh persamaan model I penelitian ini, berikutnya akan diuji pengaruh Kualitas Produk (X) terhadap Keputusan Pembelian(Y), Bentuk hipotesisnya adalah sebagai berikut :

Ho : Tidak terdapat pengaruh Kualitas

Produk (X) terhadap Keputusan Pembelian (Y)

$\mathrm{H}_{1}$ : Terdapat pengaruh Kualitas Produk (X) terhadap Keputusan Pembelian (Y)

Statistik uji yang digunakan untuk menguji hipotesis diatas adalah uji $-\mathrm{t}$ Untuk mengetahui pengaruh langsung, maka harus dilakukan uji $\mathrm{t}$ terlebih dahulu. Terlebih dahulu harus dicari nilai

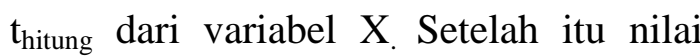
$t_{\text {hitung }}$ tersebut dibandingkan dengan nilai $\mathrm{t}$ di tabel. Jika nilai $\mathrm{t}_{\text {hitung }}$ lebih besar dari

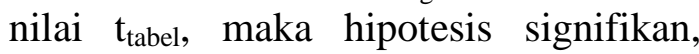
artinya bahwa $\mathrm{X}$ berpengaruh terhadap $\mathrm{Y}$ pada. Sebaliknya apabila nilai $t_{\text {hitung }}$ lebih kecil dari nilai $t_{\text {tabel }}$, maka hipotesis tidak signifikan, artinya tidak terdapat pengaruh $\mathrm{X}$ terhadap $\mathrm{Y}$.

Berdasarkan hasil pengolahan data sebagaimana terlihat pada tabel Coeffecients (Tabel 4.33) diperoleh nilai $\mathrm{t}_{\text {hitung. }}$

Tabel 10. Coefficients ${ }^{\mathrm{a}}$

\begin{tabular}{|c|c|c|c|c|c|c|}
\hline \multirow{2}{*}{\multicolumn{2}{|c|}{ Model }} & \multicolumn{2}{|c|}{$\begin{array}{c}\text { Unstandardized } \\
\text { Coefficients }\end{array}$} & \multirow{2}{*}{$\begin{array}{c}\begin{array}{c}\text { Standardized } \\
\text { Coefficients }\end{array} \\
\text { Beta } \\
\end{array}$} & \multirow[b]{2}{*}{$\mathrm{t}$} & \multirow[b]{2}{*}{ Sig. } \\
\hline & & B & Std. Error & & & \\
\hline 1 & (Constant) & 9.365 & 3.309 & & 2.830 & .006 \\
\hline & Produk & .917 & .078 & .917 & 19.268 & .000 \\
\hline
\end{tabular}

a. Dependent Variable: Pembelian

Adapun kesimpulan yang dapat diambil adalah sebagai berikut :

Tabel 11. Kesimpulan Pengujian Secara Individual

\begin{tabular}{|c|c|c|c|c|}
\hline Variabel & Nilai $_{\text {hitung }}$ & Nilai $_{\text {tabel }}$ & Kesimpulang berarti pada variabel Y (Keputusan \\
\hline $\mathrm{X}$ & 19,268 & 1,667 & Signifikanmbelian), Selain itu pengaruhnya \\
dapat digeneralisir terhadap seluruh \\
pumber : hasil perhitungan
\end{tabular}

Dari Tabel di atas terlihat bahwa $\mathrm{X}$ memiliki pengaruh yang signifikan, Artinya apabila terjadi perubahan sedikit saja pada variabel Kualitas Produk (X), maka akan langsung terjadi perubahan 


\section{SIMPULAN DAN SARAN}

Gambaran kualitas produk mobil toyota yaris di Wijaya Toyota Dago berada pada kriteria sangat baik, dimana aspek yang paling berpengaruh adalah Toyota Yaris Memenuhi Standar Keamanan Yang Baik dengan persentase 4,85\%, adapun aspek yang paling rendah pengaruhnya berada pada kriteria cukup baik adalah Toyota Yaris Memiliki Reputasi Yang Baik dengan persentase $3,18 \%$.

Gambaran Keputusan Pembelian mobil Toyota Yaris di Wijaya Toyota Dago berada pada kriteria sangat baik, dimana aspek yang paling berpengaruh adalah Membeli/ Menggunakan Mobil Toyota Yaris Merupakan Keputusan Yang Tepat Bagi Saya dengan persentase $4,85 \%$, adapun aspek yang paling rendah pengaruhnya adalah Sebelum Membeli Mobil Toyota Yaris, Saya Sudah Memastikan Sesuai Dengan Kebutuhan dengan 22,2\%.

Besarnya pengaruh kualitas produk terhadap keputusan pembelian yaitu sebesar 84,1\%, sedangkan 15,9\% kontribusi variabel lain yang tidak diteliti, misalnya kualitas pelayanan,harga, promosi.

Untuk lebih meningkatkan Kualitas Produk hendaknya manajemen Wijaya Toyota Dago dapat mempengaruhi konsumen/ pembeli dan lebih menanamkan mindset bahwa Toyota Yaris Memiliki Reputasi Yang Baik, melalui iklan baik itu media elektronik maupun cetak. Dan lebih berinovasi baik itu dari performa mesin maupun standar kemanan.

Untuk lebih meningkatkan Keputusan Pembelian hendaknya ada upaya dari manajemen untuk lebih mengoptimalkan kualitas produknya supaya konsumen merasa puas dengan produk yang dibelinya, dan pihak Wijaya Toyota Dago memastikan konsumen/ pembeli sesuai dengan kebutuhan agar tidak ada kekecewaan setelah membeli produknya. Wijaya Toyota Dago harus dapat memaksimalkan kontribusi variabel lain yang tidak diteliti yang sebesar 15,9\% misalnya dengan meningkatkan kualitas pelayanan pihak marketing maupun purna jual agar konsumen/ pembeli melakukan repeat order, guna meningkatkan keputusan pembelian yang dilakukan oleh konsumen/ pembeli.

\section{DAFTAR PUSTAKA}

George R. Terry. Diterjemahkan Oleh Dr. Winardji, SE. 2010. Asasasas Manajemen.

Buchari Alma. 2010. Manajemen Pemasaran dan Pemasaran Jasa. Bandung: Alfabeta.

Dewi Urip Wahyuni.2011.Pengaruh Kualitas Produk Terhadap Keputusan Pembelian Sepeda Motor Merek "Honda" di Kawasan Surabaya Barat

Silvya L. Mandey.2015. Pengaruh Kualitas Produk Terhadap Keputusan Pembelian Konsumen

Imam Gozali. 2002.Aplikasi Analisis Multivariate dengan Program SPSS. Semarang : Badan Penerbit Universitas Diponogoro.

Kotler, Philip dan Keller KL. Diterjemahkan Oleh Benyamin Molan. 2009 Manajemen Pemasaran Jilid 1 Edisi 12. PT. Indeks.

Kotler, Philip. 2012 Manajemen Pemasaran, Jilid I, Edisi Indonesia, Edisi Milenium,Edisi 
Kesepuluh, Jakarta : Penerbit PT. Prenhallindo

Kotler dan Amstrong.2011. Principles Of Marketing, Global Edition, 14 Edition, Pearson Education

Fandy Tjiptono. 2011. Manajemen Pemasaran Jasa, Yogyakarta, Andi Offset. 2010.Strategi

Pemasaran, Yogyakarta, Andi Offset.

George R. Terry,2003. Prinsip-prinsip Management”. PT. Bumi Aksara : Jakarta

Griffin .2004. Manajemen Jilid 1, Edisi 7.Erlangga. Jakarta

Herry Ahmad Buchory dan H. Djaslim Saladin. 2010. Manajemen
Pemasaran. Bandung: Linda Karya

Mary Parker Follet.2009. Visionary Leadership and Strategic Management. MCB University Press. Women in Management Review Vo lume 14 .Number 7 Ristiyanti Prasetijo dan John J.O.I Ihalauw. 2005. Perilaku Konsumen. Yogyakarta : Andi Sugiyono. 2013. Metode Penelitian Bisnis. Bandung:Alfabeta

Sutisna. 2012, "Perilaku Konsumen \& Komunikasi Pemasaran", PT Remaja Rosdakarya, Bandung.

Stoner.2007.Manajemen. Edisi Bahasa Indonesia. Penerbit PT. Prenhallindo, Jakarta. 